\title{
Epidemiological and Bacteriological Studies On Vesical Schistosomiasis in Ikwo Area, Ebonyi State, Nigeria
}

\author{
${ }^{1}$ UWAEZUOKE, J.C.; ${ }^{2}$ ANOSIKE, J.C.; ${ }^{1}$ UDUJIH, O.S.; ${ }^{2}$ ONYEKA, P.I.K.
}

\author{
${ }^{I}$ Department of Microbiology, Imo State University, PMB 2000,_Owerri.uwaezuoke_uwaezuoke@yahoo.com.+2348033616771
}

${ }^{2}$ Department of Animal and Environmental Biology, Imo State University, P.M.B. 2000, Owerri

\begin{abstract}
A study to determine the prevalence and intensity of vesical schistosomiasis and concomitant bacterial infection in six communities in Ikwo Local Government Area of Ebonyi State is reported. Centrifuge concentration technique for the examination of Schistosoma haematobium ova was employed. Out of the 838 persons examined, $350(41.8 \%)$ were infected with S. haematobium. Of the 430 males and 408 females examined, $175(40.7 \%)$ and $175(42.9 \%)$ were infected respectively. There was no significant difference in the prevalence of infection amongst the sexes $\left(\mathrm{X}^{2}=1.19 ; \mathrm{df}=1 ; \mathrm{P}>0.05\right)$. Over $60 \%$ of the infected persons are aged $0-20$ years. Statistical analysis revealed that the prevalence $\left(\mathrm{X}^{2}=16.65 ; \mathrm{df}=6, \mathrm{P}<0.05\right)$ and intensity $(\mathrm{t}=7.02 ; \mathrm{df}=6, \mathrm{P}<$ 0.05 ) were significantly more in persons under the age of 20 years than those above 20 years. Sixty - four $(18.3 \%)$ of the infected persons were excreting $<50$ eggs $/ 10 \mathrm{ml}$ urine while $286(81.7 \%)$ were excreting $>50$ eggs $/ 10 \mathrm{ml}$ urine. Visible haematuria increased with intensity of infection. Farmers were significantly $\left(X^{2}=9.82, \mathrm{df}=4 ; \mathrm{P}<\right.$ $0.05)$ more affected than other occupational groups examined. Of the 350 persons examined, $44(22.6 \%)$ had significant bacteriuria. The rate of significant bacteriuria increased with age in both sexes. Statistically, there was a significant difference $\left(X^{2}=9.09 ; \mathrm{df}=1 ; \mathrm{P}<0.05\right)$ in the occurrence of significant bacteriuria among the sexes. The bacterial organisms isolated are: Salmonella (2.3\%), Staphylococcus aureus $(2.0 \%)$, Klebsiella spp (1.1\%), Escherichia coli (5.7\%), Proteus spp (0.9\%) and Pseudomonas spp (0.6\%). @ JASEM
\end{abstract}

Schistosomiasis is the most important of all water impounding diseases and is the second most prevalent tropical disease after malaria in its socioeconomic and public health implications (WHO, 1998). The most current estimates show that 200 300 million people are affected by all forms of schistosomiasis in the world and about 600 million are exposed to the risk of infection, especially among those who perform daily service related to untreated waters, swimming, fishing, irrigated farming, washing and bathing in ponds and streams (WHO, 1995, WHO 1998). An estimated 120 million people are symptomatic and up to 20 million people suffer severe consequences of the infection with an estimated annual mortality rate of about 20,000 worldwide. (WHO 1998). Schistosoma haematobium, the cause of vesical schistosomiasis is present in 44 African countries (WHO, 1995) including Nigeria. Vesical schistosomiasis is by far the commonest form of the disease in Nigeria (Anosike et al., 2006). An estimated 30 million Nigerians are said to be in need of treatment annually for schistosomiasis (Anosike et al., 2003). It is worthy of note that although the occurrence of vesical schistosomiasis in Nigeria has been documented in several areas, its distribution remains inadequately understood (Anosike et al., 2001a). Also various studies have been carried out to show the prevalence and intensity of vesical schistosomiasis in different parts of Nigeria (Anosike et al., 1998, Anosike et al, 2003, Bello et al., 2003) with little emphasis on the concomitant bacterial infections associated with the disease condition (Alabaraonye and Ekwealor, 1995, Anosike et al. 2001b). The present study is an investigation on the epidemiology and bacterial infection in vesical schistosomiasis in Ikwo Area of Ebonyi State, Nigeria.

\section{MATERIALS AND METHODS}

\section{The Study Area}

The area of study is Ikwo Local Government Area of Ebonyi State of Nigeria. Ebonyi State is situated between coordinates $7^{0} 30^{\mathrm{I}}, 8^{0} 30^{\mathrm{I}} \mathrm{N}$ and between $5^{0} 40^{\mathrm{I}}$ and $6^{0} 45^{\mathrm{I}} \mathrm{E}$. The communities consist of Ndiagu Amagu, Ndiagu Echara, Ndufu Alike, Ndufu Echara, Noyo and Amanyima. These communities are part of Ikwo Local Government Area of Ebonyi State. The area is bounded in the east by part of Cross River State, in the south by Onisha Local Government Area, in the west by Ezza South Local Government Area and in the north by Abakaliki Local Government Area. Several fresh water habitats are found in these communities; some of these are man-made pools, quarry pits as well as road ditches. Members of these communities depend on streams, wells, ponds, and harvested rainwater for their water needs. The climate is typically tropical with a mean daily temperature of $29^{ \pm} 4^{0} \mathrm{C}$ for most of the year. The vegetation is typically savannah and there are two distinct seasons, the dry and wet seasons. The average annual rainfall is between 217 and $240 \mathrm{~cm}$. The setting of the area is predominantly rural and the inhabitants are mainly farmers. They cultivate mainly rice, cassava maize, bambara groundnut and live in small farming settlements, a few kilometers (or even few meters) from the rivers/streams and ponds. Most of the fresh water habitats are seasonal; in the dry season, most of the streams/rivers slow down their rate of flow and children as well as adults are seen swimming in them mostly in the afternoon. 


\section{Sample collection and analysis}

The parasitological survey was preceded by a presurvey contact during which permission was obtained for the study from the appropriate authorities in the communities. Urine samples were collected from 838 individuals randomly selected from randomly selected communities in the study area. The consent of adult subjects as well as that of parents of under-age subjects were sought for before urine samples were collected. The subjects were instructed on how to collect the urine specimens, not leaving out the last few drops of urine passed which usually contain the highest number of eggs (Cheesbrough, 1987). The urine specimens were collected between 10.00 and 14.00 hours using wide-mouthed, screw-cap plastic universal containers. The timing was to coincide with peak urinary excretion of schistosome ova. The names, sexes, ages and occupations of the sampled subjects were entered against the appropriate number on the epidemiological field form on submission of the urine samples.

Each sample container was labelled to correspond to the individual's field form number. Women on their monthly periods were recorded appropriately and excluded from visible haematuria count (Anosike et al., 2001b). This was necessary to avoid false positive results from menstrual blood (Anosike et al., 2003). The specimens were taken to the laboratory and processed for the determination of the presence of schistosome ova according to the method described by Anosike et al., (2001a). The content of the sample container was well shaken after which $10 \mathrm{ml}$ of urine was transferred with a sterile disposable syringe to a centrifuge tube and centrifuged for $5 \mathrm{~min}$. at $1500 \mathrm{rpm}$. The supernatant was decanted while the sediment was resuspended in the residual urine sample and poured onto a clean dry slide. The sample on the slide was then covered with a clean cover slip and examined under the microscope for eggs of Schistosoma haematobium. Where present, the eggs were counted and recorded as eggs $/ 10 \mathrm{ml}$ of urine. Haematuria was assayed using chemical reagent strips, Medi-test Combi-9. The test was carried out according to the manufacturer's instructions. The urine specimens were inoculated quantitatively using a caliberated wire loop (that delivers $0.001 \mathrm{ml}$ ) onto sterile Nutrient agar, Blood agar, MacConkey agar and Salmonella-Shigella (SS) agar plates for bacteriological examination. The culture plates were incubated aerobically at $37^{\circ} \mathrm{C}$ for $24-48$ hours. Samples that show growth of bacterial isolates in a count of $\geq 10^{5}$ colony-forming units (cfu/ml of urine) after overnight incubation were considered to indicate significant bacteriuria (Gerald et al., 1990). After incubation period, representative colony types (after careful examination) were picked and subcultured on surface-dried sterile nutrient agar and S-S agar (for Salmonella, Shigella species) plates. The culture plates were incubated at $37^{\circ} \mathrm{C}$ for 24 hours. The pure culture of each isolates was identified according to standard procedures (Cowan, 1993).

\section{Statistical analysis}

The prevalence of infection was calculated using percentages. Independence and relationship of community, sex, age, occupational prevalence and presence of haematuria were tested using chisquare analysis. The t-test was done to test significance of sex-related egg intensity.

\section{RESULTS}

Six communities in the Local Government Area were studied for vesical schistosomiasis and concomitant bacterial infections. Of the 838 persons examined, 350 (41.8\%) had Schistosoma haematobium infection (Table 1). The infection was recorded in all the communities with Noyo $(50.3 \%)$ having the highest prevalence followed by Ndiagu Echara (50.0\%) while Amanyima with $30.1 \%$ had the least prevalence. A chi-square analysis showed significant variation in prevalence among the communities $\left(\mathrm{X}^{2}=16.69\right.$, df $=5, \mathrm{P}<$ $0.05)$.

Table 1. Prevalence and distribution of vesical schistosomiasis in six communities in Ikwo L.G.A, Ebonyi State.

\begin{tabular}{|c|c|c|c|}
\hline Communities & No & No & $\%$ \\
\hline Ndiagu Amagu & $\begin{array}{l}\text { Examined } \\
116\end{array}$ & $\begin{array}{l}\text { Infected } \\
52\end{array}$ & $\begin{array}{l}\text { Infected } \\
44.8\end{array}$ \\
\hline Ndiagu Echara & 116 & 58 & 50.0 \\
\hline Ndufu Alike & 172 & 66 & 38.4 \\
\hline Ndufu Echara & 116 & 49 & 42.2 \\
\hline Noyo & 145 & 73 & 50.3 \\
\hline Amanyima & 173 & 52 & 30.1 \\
\hline Total & 35 & & \\
\hline
\end{tabular}

Four hundred and thirty (430) males and 408 females were examined during the study (Table 2). Of the 430 males examined, $175(40.7 \%)$ were infected while 175 (42.2\%) of the 408 females had the infection. There was no significant difference in the prevalence rate among the sexes in the study area $\left(\mathrm{X}^{2}=1.19 ; \mathrm{df}=1, \mathrm{P}>0.05\right)$. Sex - age prevalence data are summarized in Table 3. In both sexes, infection rate was highest among the age group $11-20$ years and thereafter declined with increase in age. There was a significant difference in the age - related prevalence of the infection in the study area $\left(\mathrm{X}^{2}=16.65 ; \mathrm{df}=6 ; \mathrm{P}<0.05\right)$. Table 4 shows the sex - age related intensity of Schistosoma haematobium infection in the study area. Of the 175 males infected, the highest egg load of $255 \pm 5.0$ mean eggs $/ 10 \mathrm{ml}$ of urine was observed in individuals in their second decade of life. This decreased with increase in age. In the female category, the highest mean eggs $/ 10 \mathrm{ml}$ of urine $(228 \pm 5.2)$ was also recorded in individuals in their seconds decade of life and thereafter decreased with increase in age. Statistical analysis revealed that the egg intensity was independent of 
sex $(\mathrm{t}=3.51 ; \mathrm{df}=1, \mathrm{P}>0.05)$. The sex - related egg count in Schistosoma haematobium infection in the study area is illustrated in Table 5. Thirty-six $(20.6 \%)$ male and $28(16.0 \%)$ females had light infections excreting $<50$ eggs $/ 10 \mathrm{ml}$ of urine while $22(12.6 \%)$ males and $11(6.3 \%)$ females had heavy infections excreting $>100$ eggs $/ 10 \mathrm{ml}$ of urine.

Table 6 shows the age-related haematuria in Schistosoma haematobium infection in the communities studied. Out of the 350 persons infected, 210 were both positive for $S$. haematobium ova and haematuria and 140 positive for $S$. haematobium ova but negative for haematuria. The highest rate of haematuria $(75.0 \%)$ was recorded in the age group of 11-20 years. The effect of occupation on the prevalence of vesical schistosomiasis is shown in Table 7. Farmers had the highest infection rate $(53.5 \%)$ followed by students/pupils (46.1\%), civil servants $(22.4 \%)$ traders $(20.9 \%)$ and artisans $(16.1 \%)$. Chi -square analysis showed that there is significant difference among the occupational groups $\left(\mathrm{X}^{2}=9.82 ; \mathrm{df}=4\right.$; $\mathrm{P}<0.05)$.

Table 2 Sex -related prevalence of vesical schistosomiasis in the study area.

\begin{tabular}{llllr}
\hline Communities & $\begin{array}{l}\text { Male } \\
\text { No } \\
\end{array}$ & $\begin{array}{c}\text { No (\%) } \\
\text { Examined }\end{array}$ & $\begin{array}{l}\text { Fo } \\
\text { Infected }\end{array}$ & $\begin{array}{l}\text { Examined } \\
\text { No (\%) } \\
\text { Infected }\end{array}$ \\
Ndiagu Amagu & 59 & $27(45.8)$ & 57 & $25(43.9)$ \\
Ndiagu Echara & 60 & $30(50.0)$ & 56 & $28(50.0)$ \\
Ndufu Alike & 92 & $34(37.0)$ & 80 & $32(40.0)$ \\
Ndufu Echara & 60 & $21(35.0)$ & 56 & $28(50.0)$ \\
Noyo & 73 & $33(45.2)$ & 72 & $40(55.6)$ \\
Amanyima & 86 & $30(30.2)$ & 87 & $22(29.9)$ \\
Total & 430 & $175(40.7)$ & 408 & $175(42.9)$
\end{tabular}

$\mathrm{X}^{2}=1.19 ; \mathrm{df}=1 ; \mathrm{P}>0.05$

Table 3: Sex-age related prevalence of vesical schistosomiasis in the study area.

\begin{tabular}{|c|c|c|c|c|c|c|}
\hline $\begin{array}{l}\text { Age group } \\
\text { (years) }\end{array}$ & $\begin{array}{l}\text { Male } \\
\text { No } \\
\text { Examined }\end{array}$ & $\begin{array}{c}\text { No }(\%) \\
\text { d Infected }\end{array}$ & $\begin{array}{l}\text { Female } \\
\text { No } \\
\text { Examined }\end{array}$ & $\begin{array}{l}\text { No(\%) } \\
\text { Infected }\end{array}$ & $\begin{array}{l}\text { Total } \\
\text { No } \\
\text { Examined }\end{array}$ & $\begin{array}{l}\text { No }(\%) \\
\text { Infected }\end{array}$ \\
\hline $0-10$ & 78 & $36(46.2)$ & 80 & $28(35.0)$ & 158 & $64(40.5)$ \\
\hline $11-20$ & 110 & $70(63.6)$ & 127 & $78(61.4)$ & 237 & $148(62.4)$ \\
\hline $21-30$ & 85 & $30(35.3)$ & 80 & $38(47.5)$ & 165 & $68(41.2)$ \\
\hline $31-40$ & 55 & $17(30.9)$ & 57 & $20(35.1)$ & 112 & $37(33.0)$ \\
\hline $41-50$ & 45 & $11(24.4)$ & 28 & $6(21.4)$ & 73 & $17(23.3)$ \\
\hline $51-60$ & 30 & $6 \quad(20.0)$ & 19 & $3(15.8)$ & 49 & $9(18.4)$ \\
\hline $61+$ & 27 & $5 \quad(18.5)$ & 17 & $2(11.8)$ & 44 & $7(15.9)$ \\
\hline Total & 430 & $175(40.5)$ & 408 & $5(42.9)$ & 838 & $50(41.8)$ \\
\hline
\end{tabular}

Age: $X^{2}=16.65$, df $=6 ; P<0.05$

Table: $4 \mathrm{Sex}$ - age related intensity (mean eggs $/ 10 \mathrm{ml}$ of urine) of $S$. haematobium infection in the study area

\begin{tabular}{llllllc}
\hline $\begin{array}{l}\text { Age group } \\
\text { (years) }\end{array}$ & $\begin{array}{l}\text { Males } \\
\text { No }\end{array}$ & $\begin{array}{c}\text { No(\%) } \\
\text { Examined }\end{array}$ & $\begin{array}{l}\text { Mean egg/10ml } \\
\text { Infected }\end{array}$ & $\begin{array}{l}\text { Females } \\
\text { of urine }\end{array}$ & $\begin{array}{l}\text { Examined } \\
\text { No(\%) }\end{array}$ & $\begin{array}{l}\text { Infected } \\
\text { of urine eggs/10ml }\end{array}$ \\
$0-10$ & 78 & $36(46.2)$ & $185.0 \pm 1.4$ & 80 & $28(35.0)$ & $206.0 \pm 3.5$ \\
$11-20$ & 110 & $70(63.6)$ & $255.0 \pm 5.0$ & 127 & $78(61.4)$ & $228.0 \pm 5.1$ \\
$21-30$ & 85 & $30(35.3)$ & $188.5 \pm 1.7$ & 80 & $38(47.5)$ & $186.0 \pm 1.9$ \\
$31-40$ & 55 & $17(30.9)$ & $180.0 \pm 1.9$ & 57 & $20(35.1)$ & $174.8 \pm 1.7$ \\
$41-50$ & 45 & $11(24.4)$ & $150.0 \pm 2.1$ & 28 & $6(21.4)$ & $130.4 \pm 2.1$ \\
$51-60$ & 30 & $6(20.0)$ & $100.0 \pm 1.8$ & 19 & $3(15.8)$ & $80.0 \pm 1.9$ \\
$61+$ & 27 & $5(18.5)$ & $60.0 \pm 1.9$ & 17 & $2(11.8)$ & $20.0 \pm 1.3$ \\
Total & 430 & $175(40.7)$ & $159.8 \pm 2.8$ & 408 & $175(42.9)$ & $146.5 \pm 3.1$ \\
\hline
\end{tabular}

Egg intensity in sexes: $\mathrm{t}=3.51 ; \mathrm{df}=1 ; \mathrm{P}>0.05$ Age: $\quad \mathrm{t}=7.02 ; \mathrm{df}=6 ; \mathrm{P}<0.05$

Table 5: Sex - related egg count in S. haematobium infection

\begin{tabular}{llcc}
\multicolumn{4}{c}{ in the study area. } \\
\hline Eggs/10ml & Males & Females & Total \\
of urine & $\mathrm{n}(\%)$ & $\mathrm{n}(\%)$ & $\mathrm{n}(\%)$ \\
$<50$ & $36(20.6)$ & $28(16.0)$ & $64(18.3)$ \\
$>50 \leq 100$ & $117(66.9)$ & $136(77.7)$ & $253(72.3)$ \\
$>100$ & $22(12.6)$ & $11(6.3)$ & $33(9.4)$ \\
Total & $175(100)$ & $175(100)$ & $350(100)$ \\
\hline
\end{tabular}

Table 6: Age-related haematuria in S. haematobium infections in the study area.

\begin{tabular}{llcc}
\multicolumn{3}{c}{ in the study area. } \\
\hline $\begin{array}{l}\text { Age group } \\
\text { (years) }\end{array}$ & No & No (\%) Infected & No(\%) Infection \\
$0-10$ & 64 & $41(64.1)$ & $23(35.9)$ \\
$11-20$ & 148 & $111(75.0)$ & $37(25.0)$ \\
$21-30$ & 68 & $32(47.1)$ & $36(52.9)$ \\
$31-40$ & 37 & $15(40.5)$ & $22(59.5)$ \\
$41-50$ & 17 & $06(35.3)$ & $11(64.7)$ \\
$51-60$ & 9 & $03(33.3)$ & $6(66.7)$ \\
$61+$ & 7 & $2(28.6)$ & $5(71.4)$ \\
Total & 350 & $210(60.0)$ & $140(40.0)$ \\
\end{tabular}


Table 7: Occupation - related prevalence of vesical schistosomiasis in the study area.

\begin{tabular}{llc}
\hline Occupational & No & No (\%) \\
groups & Examined & Infected \\
Farmers & 254 & $136(53.3)$ \\
Student/Pupils & 360 & $166(46.1)$ \\
Civil servants & 107 & $24(22.4)$ \\
Traders & 86 & $18(20.9)$ \\
Artisans & 31 & $5(16.1)$ \\
Total & 838 & $350(41.8)$ \\
\hline $\mathrm{X}^{2}=9.82 ;$ df $=4 ; \mathrm{P}<0.05$ &
\end{tabular}

The occurrence of significant bacteriuria in $S$. haematobium infection in relation to sex is shown in Table 8. Out of the 350 subjects positive for vesical schistosomiasis in the study area, 44 $(12.6 \%)$ had significant bacteriuria. The rate of significant bacteriuria increased with age in both sexes. Statistically, there was a significant difference in the occurrence of significant bacteriuria among the sexes $\left(\mathrm{X}^{2}=9.09 ; \mathrm{df}=1 ; \mathrm{P}<\right.$ $0.05)$. The bacterial organisms isolated include: Salmonella spp (2.3\%), Staphy-lococcus auerus (2.0\%), Klebsiella spp (1.1\%), Escherichia coli (5.7\%), Proteus spp (0.9\%) and Pseudomonas spp $(0.6 \%)$.

Table 8: frequency of significant bacteriuria in vesical Schistosomiasis patients in the study area

\begin{tabular}{|c|c|c|c|c|c|c|c|c|c|c|c|c|c|c|c|c|}
\hline \multirow[t]{2}{*}{$\begin{array}{l}\text { Bacterial } \\
\text { Organisms }\end{array}$} & \multicolumn{16}{|c|}{ Frequency in age brackets (years) of: } \\
\hline & $\begin{array}{l}0 \\
\mathrm{M} \\
\mathrm{n}=3\end{array}$ & $\begin{array}{c}10 \\
6 \\
n=28\end{array}$ & $\begin{array}{l}11 \\
M \\
n=70\end{array}$ & $\begin{array}{ll}- & 20 \\
& F \\
0 & n=78\end{array}$ & $\begin{array}{l}21- \\
M \\
n=3\end{array}$ & $\begin{array}{c}30 \\
F \\
n=38\end{array}$ & $\begin{array}{cc}31 & 40 \\
M & F \\
n=17 & n=20\end{array}$ & $\underset{n=11}{41}$ & $\begin{array}{c}-50 \\
F \\
n=6\end{array}$ & $\begin{array}{l}51-6 \\
M \\
n=6\end{array}$ & $\begin{array}{l}60 \\
\mathrm{~F}=3\end{array}$ & $\begin{array}{ll}61+ & \\
M & \mathrm{~F} \\
\mathrm{n}=5 & \mathrm{n}\end{array}$ & $\begin{array}{l}\mathrm{F} \\
\mathrm{n}=2\end{array}$ & $\begin{array}{l}\text { Total } \\
M \\
n=175\end{array}$ & $\underset{n=175}{\mathrm{~F}} \mathrm{n}$ & $\begin{array}{l}\text { Grand Total } \\
n=350\end{array}$ \\
\hline $\begin{array}{l}\text { Salmonella spp } \\
\text { Staph, aureus } \\
\text { Klebsiella spp } \\
\text { E. coli } \\
\text { Proteus spp } \\
\text { Pseudomonas }\end{array}$ & $\begin{array}{l}- \\
- \\
- \\
- \\
- \\
-\end{array}$ & $\begin{array}{c}- \\
- \\
- \\
1(3.6) \\
- \\
-\end{array}$ & $\begin{array}{l}- \\
- \\
- \\
2(2.9) \\
- \\
1(1.4)\end{array}$ & $\begin{array}{c}2(2.6) \\
- \\
- \\
6(7.7) \\
2(2.6) \\
1(1.3)\end{array}$ & $\begin{array}{l}1(3.3) \\
- \\
- \\
1(3.3) \\
- \\
-\end{array}$ & $\begin{array}{l}2(5.3) \\
2(5.3) \\
1(2.6) \\
4(10.5) \\
- \\
-\end{array}$ & 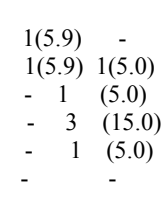 & $\begin{array}{l}- \\
1(9.1) \\
1(9.1) \\
- \\
- \\
-\end{array}$ & $\begin{array}{c}- \\
- \\
1(16.7) \\
2(33.3) \\
- \\
-\end{array}$ & $\begin{array}{l}- \\
1(16.7) \\
- \\
- \\
- \\
-\end{array}$ & $\begin{array}{l}\text { 1(33.3) } \\
\text { 7) } 1(33.3) \\
- \\
- \\
- \\
-\end{array}$ & $\begin{array}{l}- \\
- \\
- \\
1(20.0) \\
- \\
-\end{array}$ & $\begin{array}{l}1(50.0) \\
- \\
- \\
- \\
- \\
-\end{array}$ & $\begin{array}{l}2(1.1) \\
3(1.7) \\
1(0.6) \\
4(2.3) \\
- \\
1(0.6)\end{array}$ & $\begin{array}{c}6(3.4) \\
4(2.3) \\
3(1.7) \\
16(9.1) \\
3(1.7) \\
1(0.6)\end{array}$ & $\begin{array}{l}8(2.3) \\
7(2.0) \\
4(1.1) \\
\text { 1) } 20(5.7) \\
3(0.9) \\
2(0.6)\end{array}$ \\
\hline $\begin{array}{l}\mathrm{N}(\%) \\
\text { Occurrence }\end{array}$ & $0(0)$ & $1(3.6)$ & $3(4.3)$ & $11(141)$ & $2(6.7)$ & $9(23.7)$ & $2(11.8) 6(30.0)$ & $2(18.2)$ & $3(30.0)$ & $1(16.7)$ & $2(66.7)$ & $1(20.0)$ & $1(50)$ & $11(6.3)$ & $33(18.9$ & .9) $44(12.6)$ \\
\hline & & & & $\begin{array}{l}\text { Sex } \\
\text { M } \\
\text { F } \\
\text { n } \\
\text { N } \\
\text { G. }\end{array}$ & $\begin{array}{l}\mathrm{X}^{2}= \\
\text { Total }\end{array}$ & $\begin{array}{l}=9.09 ; \mathrm{df} \\
= \\
= \\
= \\
= \\
=\end{array}$ & $\begin{array}{l}=1 ; \mathrm{P}<0.05 \\
\quad \text { Male } \\
\text { Female } \\
\text { Number of } \mathrm{i} \\
\text { Number of } \mathrm{b} \\
\quad \text { Grand total } 1\end{array}$ & $\begin{array}{l}\text { infected } \\
\text { oacterial } \\
\text { number }\end{array}$ & $\begin{array}{l}\text { subject } \\
\text { isolates } \\
\text { of infect }\end{array}$ & $\begin{array}{l}\text { from sul } \\
\text { ed subje }\end{array}$ & ubjects & $\begin{array}{l}14 \\
22\end{array}$ & & & & \\
\hline
\end{tabular}

\section{DISCUSSION}

The prevalence of vesical schistosomiasis in this study was observed to be $41.8 \%$. With this prevalence, the endemicity of $S$. haematobium infection in the Ikwo area of Ebonyi State, Nigeria, has to be regarded as high and constitutes a serious public health problem which calls for priority attention in the health programms of the State and the Local Government Area. The overall prevalence obtained in this study $(41.8 \%)$ is higher than earlier observations in parts of Nigeria by Ugbomoiko (2000) in three geographical zones in Edo State (22.9\%), Okoli (2002) in selected foci in Imo State (25.1\%), Anosike et al. (2003) in the Ebonyi Benue River Valley, South Eastern Nigeria $(23.5 \%)$. A close look at the prevalences of the infection for the communities studied shows variations, which can be interpreted to mean that transmission is highest at Noyo $(50.3 \%)$ followed by Ndiagu Echara $(50.0 \%)$, Ndiagu Amagu $(44.8 \%)$. This variation as reported by earlier researchers is attributable to the variation in the degree of exposure to infection as well as the variation in the ecological conditions necessary for the breeding of the snail intermediate hosts of the disease. The age and sex-related patterns of distribution of parasitic infection in man has been widely reported (Ugbomoiko, 2000; Anosike et al,
2003). In the present study, the prevalence and severity of infection did not vary with sex but did with age of the inhabitants. The younger age groups recorded higher infection rates and egg burden than the older subjects. Variation in exposure to schistosome infection in individuals influence distribution and intensity (Anosike et al, 2003). According to Anosike et al. (2002), children of school age form the bulk of the contact with contaminated natural water bodies especially stagnant pond in most endemic foci in Nigeria and else where. The finding in this study of an initial rise in infection in young persons in both sexes followed by a decrease in older age groups corroborates those of Anosike et al (2001b), Anosike et al. (2003) and may be due to equal exposure to the infective stage of the parasite by similar age groups.

The age group 11-20 years in both sexes had the highest prevalence and intensity of infection, indicating that transmission rate in children and adolescents is high. Hence, this group contributes significantly to the potential contamination of the environment and consequently to the transmission of the disease. The observed drop in prevalence in the older age groups could be due to either a decrease in transmission rate due to reduce water 
contact or reduced survival and fecundity of parasitic worms already in the human host which is consistent with the slowly acquired immunity to parasitic infection (Ogbe, 1995). In any intervention programme, therefore, focal attention should be on the most heavily infected, which in this study, is the $11-20$ year age - group. Considering the egg count load of the infection, majority of the infected persons had $>50$ eggs $/ 10 \mathrm{ml}$ of urine. The World Health Organization (WHO, 1985) set a threshold egg concentration of $>50$ eggs $/ 10 \mathrm{ml}$ of urine to indicate the risk of $S$. haematobium morbidity at the level of the individual. Haematuria was observed in $60.0 \%$ of the infected persons. Haematuria in $S$. haematobium infection in the study showed similar age - prevalence pattern as a greater number of individuals within the $11-20$ year age bracket $(75.0 \%)$ had haematuria. Haematuria as observed herein, decreased with increase in age, a phenomenon attributable to the waning of egg hypersensitivity with age (Nduka et al., 1995). Considering the occupation-related prevalence, farmers had the highest infection rate of $53.5 \%$ compared to the other occupational groups. These people are mainly farmers who are easily recognized as hired labourers in swampy rice fields. Their occupation imperative predisposes them to infection (Anosike et al; 2002). The students/pupils recorded the second highest infection rate. These groups fall within the age group of $0-20$ years. The first two decades of life is the age of active life, hence increased human activity increases the predisposition of people in this age group to infection especially through increased water contact (Anosike et al., 2003; Uwaezuoke et al., 2006)

The observation of significant bacteriuria in cases of vesical schistosomiasis suggests the possibility of secondary bacterial infection. An overall prevalence of $12.6 \%$ of significant bacteriuria in patients with vesical schistosomiasis was obtained in the study. The prevalence of bacterial infection as a consequence of vesical schistosomiasis has been assessed by other workers. Anosike et al. (2001b) recorded a prevalence of $67.2 \%$ bacteriuria amongst infected persons, Adeyeba and Ojeaga (2002) observed a prevalence of $75.4 \%$ bacteriuria in persons infected with $S$. haematobium in their study in Ibadan. The association between schistosomal and bacterial infections could result from a relationship in which the bacteria either become fixed on the cutaneous surface of the worm in clearly defined places (Penaud et al., 1983) or colonize the caecum of the parasite (Ottens and Dickerson, 1972). It is not surprising also that many bacterial species could be isolated in significant amount from urinary schistosomiasis patient's urine following the supply of blood to them by the bleeding tissues resulting from the migrating activities of the spined eggs of $S$. haematobium. The torn surfaces bleed, releasing blood for microbial utilization and also provide sites for microbial attachment and proliferation. The distribution of significant bacteriuria in infected persons by sex in the study showed that females had higher prevalence than males and the prevalence increased with age. Anosike et al. (2001b) similarly reported a higher prevalence of bacteriuria in females $(61.5 \%)$ than in males $(38.5 \%)$. It has been reported (Sleigh and Timbury, 1986; Kunin, 1987) that the risk of acquiring bacteriuria varies with age and sex. Pfau et al. (1983) reported that in adulthood, it is more prevalent in women than men and its prevalence increases with age, sexual activity and the population under study. This study has shown that vesical schistosomiasis is endemic in the Ikwo area of Ebonyi State, Nigeria, and could be a threat to important socio-economic activities in the area. There is urgent need therefore, for the Local Government Area authority as well as that of the State Government to formalize and establish feasible control programmes in the area. This work also suggests that bacteriological examination be carried out for every vesical schistosomiasis patient to either confirm or rule out any associated urinary tract infection. This is to arrest any health implications arising from urinary tract infections.

\section{REFERENCES}

Adeyeba, OA; Ojeaga, SGT (2002). Urinary schistosomiasis and concomitant urinary tract pathogens among school children in metropolitan Ibadan, Nigeria. African Journal of Biomedical Research. 5:103-107.

Alabaraonye, FFM; Ekwealor, I A (1995). Some aspects of epidemiology of urinary schistosomiasis in Agulu Lake, Nigeria. Journal of Microbiology. 10:9-12.

Anosike, JC; Nwoke, BEB; Njoku, AJ (1998). The validity of visible haematuria in community diagnosis of urinary schistosomiasis infection. Journal of Helminthology. 75: 1-3

Anosike, JC; Njoku, AJ; Nwoke, BEB; Okere, AN; Okoro, UO; Obiajuru, IOC; Ogbulie, JN; Ohiaeri, CN; Ene, EO; Njoku, CJ (2001b). Epidemiological and bacteriological findings in some schistosomiasis endemic foci in Ebonyi State, Nigeria. International Journal for Environmental Health and Human Development. 2 (2): 13 -19

Anosike, JC; Nwoke, BEB; Okere, AN; Alozie JI; Okoro, UO; Nwosu, DC; Ogbulie, JN; Amadi, ANC (2001a). Endemicity of urinary schistosomiasis in the North Central Zone of Abia State, Nigeria. International Journal for Environmental Health and Human Development. 2 (2): 5- 12 . 
Anosike, JC; Njoku, AJ; Nwoke, BEB; Ajero, CMU; Osagiede, UR; Okoro, OU; Nwosu, DC (2002). Epidemiology of urinary schistosomiasis in Ebonyi State, Nigeria. International Journal for Environmental Health and Human Development. 3 (1): $1-9$

Anosike, JC; Okere AN; Nwoke, BEB; Chukwu, JU; Nwosu, DC; Njoku - Tony, RF; Oguwuike, TU; Ezike, MN; Okogun, RA; Obasi, CU; Ogbusu, FI; Onyirioha, CU; Ajero, CM; and Dike, MU (2003). Edemicity in the Ebonyi Benue River Valley, South Eastern Nigeria. International Journal of Hygiene and Environmental Health 206: $1-6$

Anosike, JC; Oguwuike, UT; Nwoke, BEB; Asor, JE; Ikpeama, CA; Nwosu, DC; Ogbusu, FI (2006). Studies on vesical schistosomiasis among rural Ezza farmers in the South Western border of Ebonyi State, Nigeria. Annals of Agriculture, Environment and Medicine. 13:13-19.

Bello, YM; Adamu, T; Abubakar, U; Muhammad, AA (2003). Urinary schistisomiasis in some villages around the Goronyo Dam, Sokoto State, Nigeria. The Nigerian Journal of Parasitology. 24: 109-113.

Cheesbrough M (1987). Medical Laboratory Manual for Tropical Countries. Vol. $12^{\text {nd }}$ edn. Tropical Health Technology/butterworth and Co. Ltd., Cambriageshire/Kent.

Cowan, ST; (1993) Cowan and Steel's Manuel for the identification of Medical Bacteria. Cambridge University Press, London.

Gerald, LM; Douglas, RG; Benette, JE (1990). Principles and practice of infectious diseases. $3^{\text {rd }}$ edn. Churchill Livingstone, New York.

Kunin, CM (1987). Detection, Prevention and Management of Urinary Tract Infection. $4^{\text {th }}$ edn. Lea and Febiger, Philadelphia.

Nduka, FO; Ajero, CMU; Nwoke, BEB (1995). Urinary schistosomiasis among children in an endemic community in South - East Nigeria. Applied Parasitology. 36(1): 34 - 44.

Ogbe, MG (1995). Schistosoma haematobium: A review of the relationship between prevalence, intensity and age. Nigerian Journal of Parasitology. $16: 40$ - 44 .

Okoli, CG (2002). Ecology, prevalence and distribution of urinary schistosomiasis and its snail vector in selected foci in Imo State, Nigeria. Ph.D Thesis, Federal University of Technology, Owerri, Nigeria.

Ottens, H; Dickerson, G (1972). Studies on the effects of bacteria on experimental schistosome infections in animals. Transactions of the Royal Society of Tropical Medicine and Hygiene. 66:85107.

Penaud, A; Nourrit J; Chapoy, P; Alessandrini, P; Louchet, E; Nicoli, RM (1983). Bacterioparasite interactions: Enterobacteria and schistosomes. Tropical Medicine. 43:331-340.

Pfau, A; Sacks, T; Engelstein, D (1983). Recurrent urinary tract infections in premenopausal women: prophylaxis based on an understanding of the pathogenesis. Journal of Urology. 129:1153-1160.

Sleigh, JD; Timbury, M (1986). Notes on Medical Bacteriology. $2^{\text {nd }}$ edn. Churuchill Livingstone, New York.

Ugbomoiko, US (2000). The prevalence, incidence and distribution of human urinary schistosomiasis in Edo State. The Nigerian Journal of Parasitology. 21:3-14.

Uwaezuoke, JC; Anosike, JC; Nwoke, BEB (2006). Vesical schistosomiasis in North Eastern part of Imo State, Nigeria. International Journal of Natural and Applied Sciences 2(3): 219-224.

WHO (1985). Control of Schistosomiasis: Report of a WHO Expert Committee. Technical Report Series, 728. WHO Geneva.

WHO (1995). Identification of high risk communities for schistosomiasis in Africa. A multi country study. Social and Economic Research Project. TAR/SER/PRS/15. WHO Geneva. P. 83.

WHO (1998). Guidelines for the evaluation of soiltransmitted helminthiasis and schistosomiasis at community level. A guide for manager of control programmes. WHO/CTD/SIP/98.1 